\title{
The Improvement of Ar-Rahn (Islamic Pawn Broking) Enhanced Product in Islamic Banking System
}

\author{
Dziauddin Sharif ${ }^{1}$, Amir Shaharuddin ${ }^{1}$, Nurul Aini Muhamed ${ }^{1}$, Nasif Sidquee Pauzi ${ }^{2} \&$ Mohamad Zaid Mohd \\ $\mathrm{Zin}^{2}$ \\ ${ }^{1}$ Faculty of Economics and Muamalat, Islamic Science University of Malaysia, Malaysia \\ ${ }^{2}$ Centre of Islamic Thought and Understanding, MARA University of Technology, Malaysia \\ Correspondence: Mohamad Zaid Mohd Zin, Centre of Islamic Thought and Understanding, MARA University of \\ Technology, Malaysia. E-mail: zaiduitm@gmail.com
}

Received: October 13, 2012 Accepted: November 14, 2012 Online Published: January 28, 2013

doi:10.5539/ass.v9n2p36 URL: http://dx.doi.org/10.5539/ass.v9n2p36

\begin{abstract}
In a modern economy, there is no doubt that banks play a major role in generating the economic and financial growth. The individuals, the communities and the organizations are reliant on banks as their financial resources and necessities fulfillment. Their dependence to the banks has led them to engage a variety of contracts especially a debt-based contract. This contract required them to bond with the banks in the long period. Therefore, the various innovation products are designed to ensure the debtors are able to engage in an Islamic way and the banks are able to attain their income generation at the same time. While the debt contract is almost impossible to be implemented in Islamic banking system nowadays as it will lead to an interest, a modification process on the innovating sale contracts that have a commercial value for the bank is the only way for them to offer a debt-based contract to the people. Thus this paper attempts to explore the potential of ar-rahn product to solve the current problem. It tries to propose the enhancement of ar-rahn existing product offered by the bank and pawnshop as a good alternative to the financing products. The explored features of the potential of ar-rahn consist of the suitability of concepts adopted in the product, the possibility of longer repayment's period, the minimization of the shariah and economic issue of ujrah fee, the possibility of offering more than RM10, 000 borrowing money and the expansion of receivable pledge item. While the exploration of those features is discussed in a foundational and ideal basis, it is hoped to stimulate further investigation in the future.
\end{abstract}

Keywords: improvement, ar-rahn enhanced products, Islamic banking system

\section{Introduction}

The legitimacy of ar-rahn has been clearly stated in al-Quran and the prophetic tradition. It is further explained by the Muslim scholars from a various field and background since the salafi period until the challenging modern days. Ar-rahn is not only been discussed in the Islamic jurisprudence books but also in other discipline of knowledge such as Islamic theology and Islamic history. In Islamic theology for instance, there is a topic about the acceptance of ar-rahn been discussed by Al-Tamimi (al-Tamimi, 1991). Similarly in Islamic history, al-Sahmi (al-Sahmi, 1989) was also talking about ar-rahn but he presented it in a narrative way during prophet days. Obviously, the concept of ar-rahn is well known not only among jurisprudence scholars but the scholars of other discipline of knowledge as well.

However, the needs of the practicality of ar-rahn in banking industry is more insisting than just a conceptual ruling in a book made previous works were not good enough to cover the shortfall. A modification process on the contracts that have both features of commercial value and shariah compliance are the only concern for the Islamic bank to offer a debt-based contract to the people. Although the existing ar-rahn product has undergone that process, a huge potential still need to be explored and infused by Islamic banks. The ar-rahn product should no longer become the second choice after the financing scheme, but to become an equal alternative in the market today. Thus, some features available to the existing ar-rahn are crucial to be reviewed for the improvement and betterment of its potential.

\section{Literature Review}

For in-depth research on the law of ar-rahn, the books of Quranic exegesis, hadith and classical text of Islamic 
jurisprudence specifically should become the priority of references. In Quranic exegesis, Ibn Kathir is one of the scholars that explained very well about ar-rahn regarding surah al-Baqarah verse 283 (al-Qurashi, 1999). Bukhari and Muslim alone have recorded at least ten to eleven text of various degree of hadith about ar-rahn in their respective books, Sahih Bukhari (al-Bukhari, 810-870M/194 - 256H) and Sahih Muslim (al-Naisaburi). Similarly, the jurists from every age and school of thoughts have contributed tremendous and magnificent works through discussion of a particular topic. They were devoted throughout their life in seeking truthful inputs for every angle of the Islamic law. The great names such as al-Shaybani and al-Sarakhsi of Hanafi, al-Mawardi, al-Syirazi, al-Rafi'i and al-Nawawi of Shafi'i, al-Dasuqi, al-Dardir, al-Khalil and al-Qarafi of Maliki as well as Ibn Qudamah of Hanbali are indeed become "a living legend" to the modern scholars in Islamic law. Age by age, the great collection of ar-rahn issues had flourished through the meticulous process and methodology developed by them. The reviewing process, the debate of the issues, the comparative methods, the evidences they used and the principles of jurisprudence that they held became the extraordinary efforts that nobody could deny.

The breadth of ar-rahn discussion as what has been reviewed by al-Du'ailaj (al-Du'ailaj, 1986) in his thesis is probably the most comprehensive works ever exist in the academic research. The concepts, the principles, the rulings, the pillars and the issues related ar-rahn has been explained in details through his work. Meanwhile its views, evidences and determining conclusion from the long debate of jurists in schools or inter schools were presented in a very structured format. It is also serves the simplified idea of a huge collection of views from jurists of four schools and obviously make later researcher easily to digest its rulings. For instance, the author concluded that the definition of ar-rahn by Hanbali scholars was differed than the others as they focused on the pledge item while the other three schools (Hanafi, Shafii and Maliki) defined ar-rahn as a pledge contract.

For the time being, the works of Masae (Masae, 2011) and Shakhanbeh (Shakhanbeh, 2010) are the latest efforts of bringing the conceptual ruling into a practical contract in a modern system. The works of Masae that focuses on the traditional pawn broking in southern Thailand is about to bring a traditional practice of ar-rahn into a mainstream model. The analysis of the author made about ar-rahn practice in the society was sufficient and it can be seen through the expansion of the pledge in the contract as what have been suggested and discussed by the salafi jurists' long time ago. However, the discussion of the practice of ar-rahn in Koperasi Islam Ibn Affan Pattani (Islamic Cooperative of Ibn Affan of Pattani, Southern Thailand) was lacking of suggestion in developing a good model of ar-rahn especially to become a good alternative to the existing financing products and services. Meanwhile, the work of Shakhanbeh had brought up an idea on how the collaterals in kind can be a sort of investment agent. This idea came as a result of the huge size of collaterals in banks and therefore the potential of ar-rahn contracts could be expanded and enlarged in term of size of amount convoluted. The author had examined the investment legality by reviewing the scholars' views in accordance with shariah rules. It is one of the options for the bank to overcome the difficulties and problems it faces regarding the disposition of these collaterals since the bank does not have the title to these assets.

The research on the utilization of the pledged item is indeed crucial. Thus, many researchers had worked on it and obviously it was not a new idea. Previously, Meera (Mydin Meera, 2009) has suggested that the needs of the conversion of the unredeemed gold items into gold dinars and pushed back into the economy. While in this way the gold can be sold for market price, he claimed that it can be made into a mode of investment for the people and if circulated as a complementary currency, it can further encourage economic activity, production and employment in the economy. Another detailed work of the pledge's utilization has been done by Yunta (Yunta, 2007). The author discussed the law and the views of jurists on these issues and found that it was permitted with certain condition.

The works of Mukhlas (Mukhlas, 2010) has discussed ar-rahn by using the composite contract of Murabahah and ar-rahn contract. The author examined the composite contracts of Murabahah and ar-rahn at Islamic pawnshop branch Mlati Yogyakarta Sleman and it shall be able to serve the alternative of the financing products in terms of the amount of borrowing cash and the competitive profit rates. However, the author suggested that certain barriers need to be examined such as the legal issue of conflict within the muqtada al-aqd (the objective of the contract) of the composite contracts, the knowledge of the operators and the good facilities of pledge storage. The concerns over the Islamic legal problems are actually shared by Khir (Khir, 2011) when there is a need for modification of this product in the future. The author mentioned this contractual arrangement involves tawarruq (the process of purchasing a commodity fir a deferred price) through commodity murabahah (the sale of an item for a pre-agreed selling price which includes a pre-agreed profit mark-up over its cost price) is a form of hiyal-based contract (trick based contract) and allowable on a temporary basis only. Hence, it cannot be used continuously without looking for a new alternative.

Even though Shakhanbeh, Mukhlas and Yunta have studied a variety of composite contracts in ar-rahn products, 
certain issues are necessary to be discussed further. For instance, Mukhlas has studied the gold that bought by the customers (pledgor) from the pawnshop they engaged (using murabahah) could provide financial assistance to the customer. However, the issue of the existence of the gold bar as a pledge and the higher price from a normal market price resulted from earlier purchasing of gold (between pawnshop and gold manufacturer) could contributing to the situation of gharar (uncertainty). The profit amount of murabahah determined by the pawnshop could possibly represent the gold price in the future if it is bonded in a long term. The sample of calculation on how the pawnshop gained from the deal is insufficient as the sample shown for a short term basis. This fretfulness arises when it comes to the long term (such as 20 years) as the existing of financing selling price determined by the bank's today is representing the expected selling price in the future. If this happened, once again the issue of riba (usury) and gharar (uncertainty) will emerge.

As the repayment of the debt should be well proceeded, the banks might be struggled to determine the appropriate rate of ujrah (safekeeping) or profit. This dilemma could arise when the bank is only allowed to secure its principal sum of financing (Section 242-243 of National Code Land (Act No. 56), 1965), not the financed principal sum plus a profit margin as mentioned in PSA (Property Sale Agreement). Under the PSA, the bank sells the property to the customer at an agreed price that will be paid by the customer on deferred basis. In pursuant to the PSA, the bank requires the customer to execute a registrable charge in favour of the bank in order to secure the payment of sale price. This registrable charge acts similar as a pledge that will be registered under the virtue of section 241 of the National Land Code (Saiful Azhar Rosly , 2007). Through the composite contract of ar-rahn and murabahah, banks will secure their financing at purchasing price. If this happened, the bank will face the troublesome if customers are defaulting as the pledge is only secure the financing amount at a purchasing price. In the case study of Mukhlas, the pawnshop probably in a risk if the customer defaulting the monthly payment and thus unsecure the total amount of financing which determined at a selling price. For example, the gold of 60 gram that worth RM10,000 at a purchasing price is sold to the customers plus profit margin $10 \%$ a year is about RM11,000 can only be secure for RM10,000 but not RM11,000. Even the value of gold that the pawnshop restrained at their possession could be appreciated along the way of financing period; the pawnshop has to give back the surplus to the customers from the pledge auctioning or selling. Unless the section 241 to be adjusted, this composite contract seems inappropriate to be held in the Malaysian law. This situation has been labeled earlier by Uzaimah (Uzaimah Ibrahim, 8-10th August 2006) as one of the failures of Maqasid Shari'ah (the objectives of Islamic Law) to be fulfilled. The new system or law probably needs to be designed to give the fairness for both contracting parties (bank and customer) when it comes to the debt-based contract in the long period.

In the perspectives of law, the effort of Shakhanbeh and Uzaimah in discussing the principle of ar-rahn and its application at the bank was respectable and seems to be appropriate in providing cash to the customer in a big volume and a long period. However, the contract of ar-rahn in this paper is focusing on the development of ar-rahn product as a whole instead of ar-rahn contract that been included in other financing products. The adhesive of ar-rahn contract into the financing products is bringing ar-rahn product into nowhere. It should be the other contracts to be composited into the ar-rahn product, not otherwise. It is about the matter to prioritize and to strengthen. This work is giving the special interest on the ar-rahn product as its carries different spirit and philosophy. Even though, Mukhlas has studied the contract of Murabahah and ar-rahn in the ar-rahn products, the legal issue as stated earlier and the accessibility of getting big volume of loan is not yet to be resolved. Thus, the new work regarding this interest is significantly important in knowing its potential at certain extents it could.

The studies conducted by Salleh (Salleh, 2005) and Mohamad (Mohamad, 2004) are not so contributed to the development of potential of ar-rahn product. This can be seen when their findings are investigated about the execution of ar-rahn product at the pledge institutions and its validity related to the concept of Islamic pledge. If one wishes to know the applicability of shari'ah compliance in a particular institution, then this study could provide it. Except for the issue related to elements of coercion in giving hibah (gift) for pledge redemption at MGIT found by Mohamad, the other aspect shows this study is an improvisation of the earlier studies by (Hussein, 2000) and Seman (Seman, 1994). Meanwhile, it is contradictory when Salleh stated lower rate of ujrah (wage) regarding her finding at the four pledge institution she investigated in Perlis with the calculation of the loan plus ujrah rate towards the end of the redemption as stated in the subtopic of real ujrah fee's calculation of this work. This finding most probably concluded within the similar products of ar-rahn and obviously, it is not the comparative rate to the financing products.

Mohamad (Mohamad, Pawnbrokers Act 1972: An Analysis from the Islamic Perspective (Original text: Akta Pemegang Pajakgadai 1972: Suatu Analisa Dari Perspektif Islam), 1995) analyses the Pawnbrokers Act 1972 from the Islamic perspective by referring to sections that have conflicts with Islamic law. The study found that 
there are two sections in the act that contradict Islamic law, namely section 17 which allows the pledgee to take advantage of borrowing and section 23 (a) that allows the pledgee to have the pledge that are not redeemed if the loan not exceeding RM100. Similarly, Naim (Naim, 2004), concluded some practices adopted by the Islamic system are "not truly in compliance" with the teaching of the Islamic law. The author found al-rahn scheme still contains elements of usury in the transaction. The author also proposed of giving "good loan" which is backed by the pledged should be the responsibility of government and millionaire to prevent the folk continuously trapped in the financial system.

While improving ar-rahn enhanced scheme into a form of innovation in the banking system, its current acceptance level and the performance of efficiency should be a good reason of why its potential is extensively being explored. The latest acceptance study has done by Bashir (S.A. Bashir Ahmad et.al, 2012). The study demonstrated that all the identifiable constructs were substantial to very strong and significantly correlated with the customer acceptance towards pawn broking offered by Ar-Rahnu MAIDAM Dungun. Selamah and Ghafar (Selamah Maamor and Abdul Ghafar Ismail, 2010) have studied the efficiency of ar-rahn by measuring the secondary data for 2006 across several ar-rahn operators including Bank Rakyat, Permodalan Kelantan Berhad (PKB), Muasasah Gadaian Islam Terengganu (MGIT) and Cooperatives under Yayasan Pembangunan Ekonomi Islam Malaysia (YaPEIM). Even though they found the highest average efficiency score among categories of ar-rahn used is Bank Rakyat, they suggested ar-rahn outlets have to improve their efficiency because only $24 \%$ of 111 outlets operate at the efficient level. Abdul Ghafar Ismail \& Nor Zakiah Ahmad (1997) has suggested the increasing amount for loan as a microenterprise credit in Malaysia was expectedly increased over the 1990's resulted from the industrialization. Nevertheless, this idea should remain as a significant indicator for consideration at this day by the banks as the cost of living is continuously snowballing and reinforced by the continued upsurge in gold prices.

\section{Research Method}

The paper adopts domain analysis approach. The approach draws on that of Spradley (Spradley, 1979) which is based on the identification within the content of the data of key topics, referred to as domains, and the relationships between them. The analysis is made through the identification of the main issue or 'domain' resulted from the observation of the problem. In this case, the exploration of the capability of ar-rahn to become a good alternative to the existing financing products will be examined and discoursed.

The exploration of any changes of the features is considered the improvement to ar-rahn products. Thus, the main issue of the potential of ar-rahn will then be grouped in more details as to constructing taxonomy of the subcategories (subdomain). The specification of what was actually researched will be described in details of the sub-domain. Lastly, the final of an overall picture will be known and concluded as the exploring process of the inter-relationships between the various domains, subdomains and its details is associated along the way.

Based on the figure 1, there are five features of ar-rahn to be explored which are the suitability of concepts, repayment's period, the ujrah fee issues, financing/loan amount and the receivable of the pledged item. These five features are reviewed in giving the answers of the potential of ar-rahn in becoming a good alternative to the financing scheme of today's practice. Except the receivable pledged item, most of the features are further reviewed in inter-relation analysis where the feature needs to discuss together with other feature.

The first feature for instance, is about the suitability of the concepts used in ar-rahn product. The review of the linkage of the ujrah fee to the value of the pledge is discussed under the minimization of shariah (Islamic Law) issue for ujrah fee. Similarly, the second feature to be studied together with the relevant third feature of competitive ujrah rates and the repayment's period should be discussed with the amount financing or loan to be offered. The inter-relation analysis will be further discussed in the finding section. 
Domain (Key topic) Sub-domain (Enhanced features)

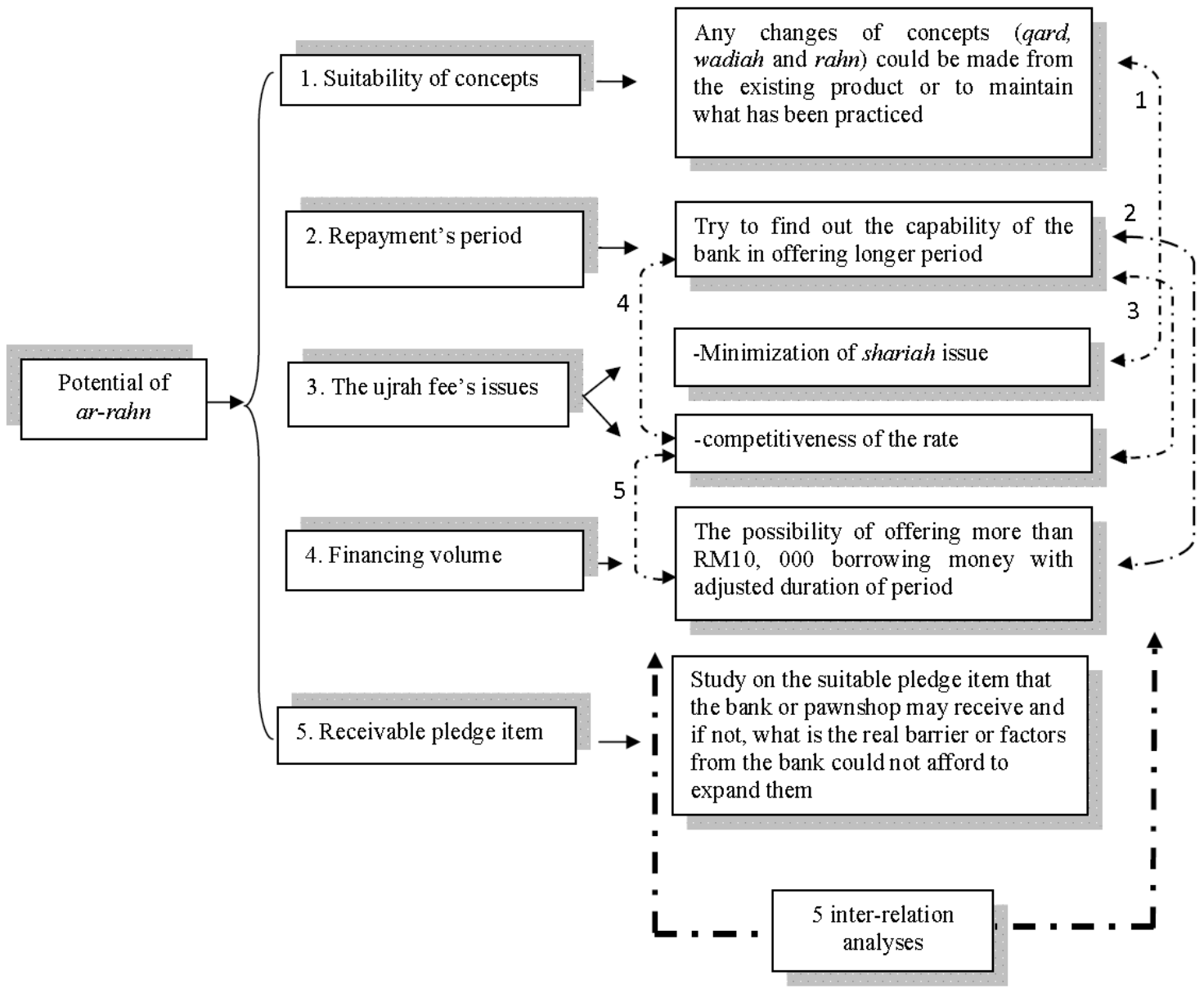

Figure 1. The research model based on the Spradley (1979)'s domain analysis interpretation

\section{Discussion}

Table 1. Comparative features of selective financing products and ar-rahn in Malaysia

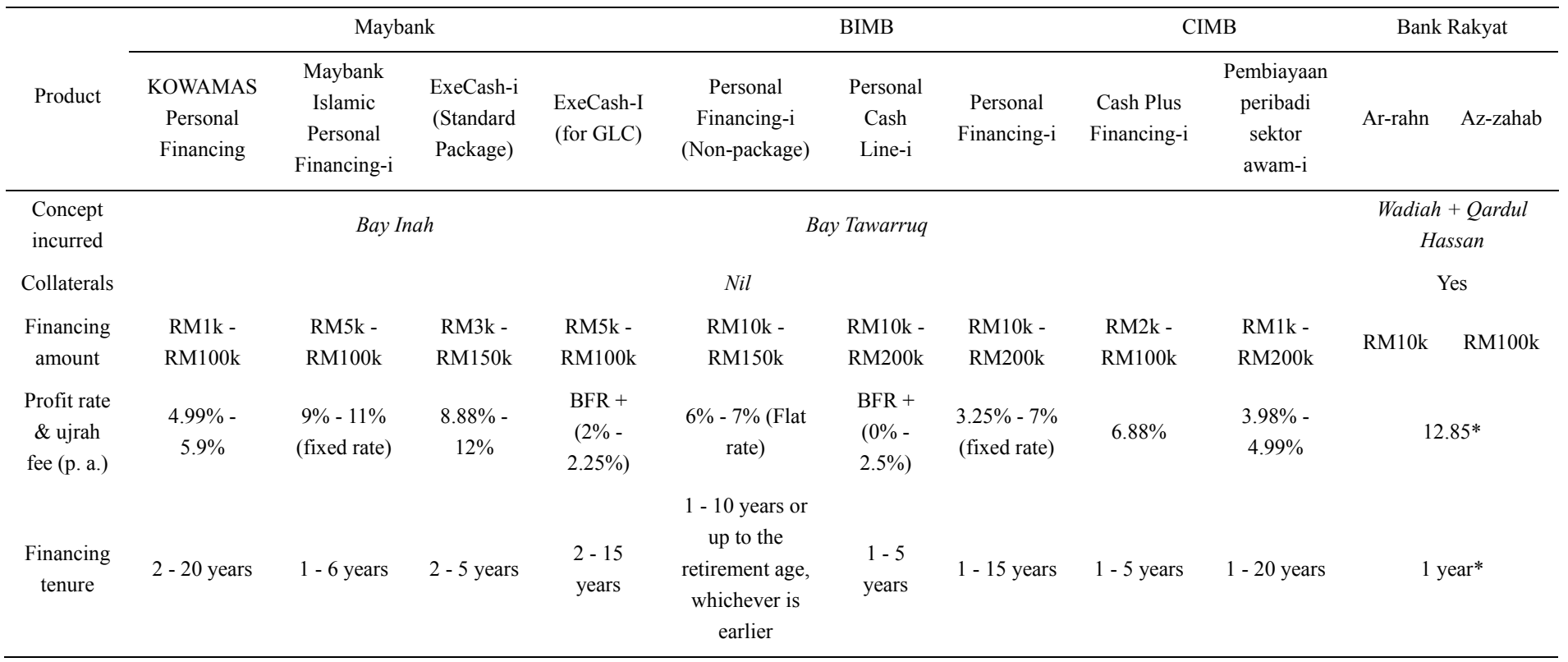

Source: www.maybankislamic.com.my, www.bankrakyat.com.my

www.cimbbank.com.my,

www.bankislam.com.my, 
The discussion of the explored features and their results are mainly based on the table 1 above.

*Assumed that the customers were chosen the maximum amount of loan from the pawned item. If the amount of loan is below the maximum amount he could possibly engaged, the ujrah fee will be relatively higher as the ujrah is based on the value of marhun (pawned item).

**Noted that the current duration of ar-rahn is 6 months, but can be extended for another 6 months (multiple extensions) subject to settlement of safe keeping fee for the past 6 months. This will imply the new ujrah fee for the new extension period.

The real rate of ujrah fee

The bank and pawnshop have undisclosed the real rate (in percentage) in their documents. This probably avoids the direct linkage of ujrah fee to the value of the loan. What are they do is to state the amount of ujrah in each RM100 of the pledge value. However, the customers should be revealed academically the real rate of ujrah fee so that they realize the higher rate of it. Thus, the calculations of deriving $12.85 \%$ are as follows:

Ujrah fee in 6 months

$10,000 / 100 \times 0.75 \times 6$

$=\mathrm{RM} 450$

Total ujrah (safekeeping) in a year - (a new agreement been made for another 6 month of extension period)

$450 \times 2$

$=$ RM900 (assume that there no increasing or decreasing value of the pledge, if happens the ujrah fee may varies)

The rate of ujrah (in percentage)

$900 / 7000 \times 100-$ (Financing up to $70 \%$ of the pawned gold value)

$=12.85 \%$

$1^{\text {st }}$ feature: The suitability of contracts adopted in the product

In discussing ar-rahn product, the main thing that needs to be addressed is the qard contract. Based on the evidence of al-Quran and Sunnah, ar-rahn occurs when a person wishes to use money or goods but have to borrow or to buy it in a deferred time due to the absence or lack of money to deal with. Then, ar-rahn contract is engaged as a guaranty for the borrowing money to be paid back after one has borrowed. It is clear, though it is named ar-rahn product but the main contract is a debt contract and ar-rahn functioned as a proponent of the debt contract. Therefore, the discussion on debt contracts should be seen first before contract ar-rahn will go for signings.

According to Khir, it is difficult for a scheme or banking products to satisfy for both: the commercial aspect, namely the profit to the bank and at the same time to comply with the shari'ah. However, the implementation of takyif fiqhi will be able to minimize issues related to shari'ah. There are four allowable composite contracts suggested by Khir namely the takyif fiqhi models are as follows:

$1^{\text {st }}$ model: Combination of wadiah bi ajr (trust by wage imposed), qard hasan (benevolent loan) and rahn al-wadiah (pledging the titem)

$2^{\text {nd }}$ model: Combination of tawarruq (through Commodity Murabahah) and rahn (pledge)

$3^{\text {rd }}$ model: Qard Hassan (benevolent loan) with encouragement of giving hibah (gift).

$4^{\text {th }}$ model: Combination of rahn (pledge) and qard hasan (benevolent loan)

Among the four models that have been studied by him, only two models that is truly frees from the element of riba, hilah and gharar, which is the third and fourth model. But these third and fourth models could not be implemented in Islamic banking on its characteristics that are not able to generate profits. Thus, the products using these contracts were not practical to be offered (Khir, 2011). Thus, the first and second models are suggested but have only one disadvantage in relation to the shariah aspect of the product, which is the element of suspicion of riba (usury) and hiyal (trick). In first takyif fiqhi model, the whole contractual arrangement may constitute the element of qard jarra manfa'ah (Loan that carries benefits) (Yamani, $1403 \mathrm{~h}$ ) while in second takyiffiqhi model; the contractual arrangement involves tawarruq, which is a form of hiyal-based contract. (Khir, 2011) 
For the first model, qard jarra manfaah may happen when the bank will look at the value of wadiah item while offering a debt-based contract to the customer. Even the wadiah item is already stored during the engagement of wadiah bi ajr contract; the maximum loan given by the bank may connect to the value of the wadiah item stored by the bank during the first contract. Meanwhile, a form of hiyal-based contract in the model 2 may happens when the bank is reselling the gold to the customer for a second time. This second time of reselling process may be questioned as the bank is not a jewelry shop; thus the sale of the gold to the bank is a trick to get some cash. This contract is more similar to bay inah (the process of purchasing a commodity for a deferred price determined through bargaining or Mark-up sale and selling it to a similar party for a spot price as to obtained cash) than tawaruq the process of purchasing a commodity for a deferred price determined through Musawamah (bargaining) or Murabahah (Mark-up sale) and selling it to a third party for a spot price as to obtain cash ) where the bank has the intention to resell the gold to a similar customer who had been sold to them before. Figure 2 below is the process on how the bank may look at the value of the stored wadiah item.

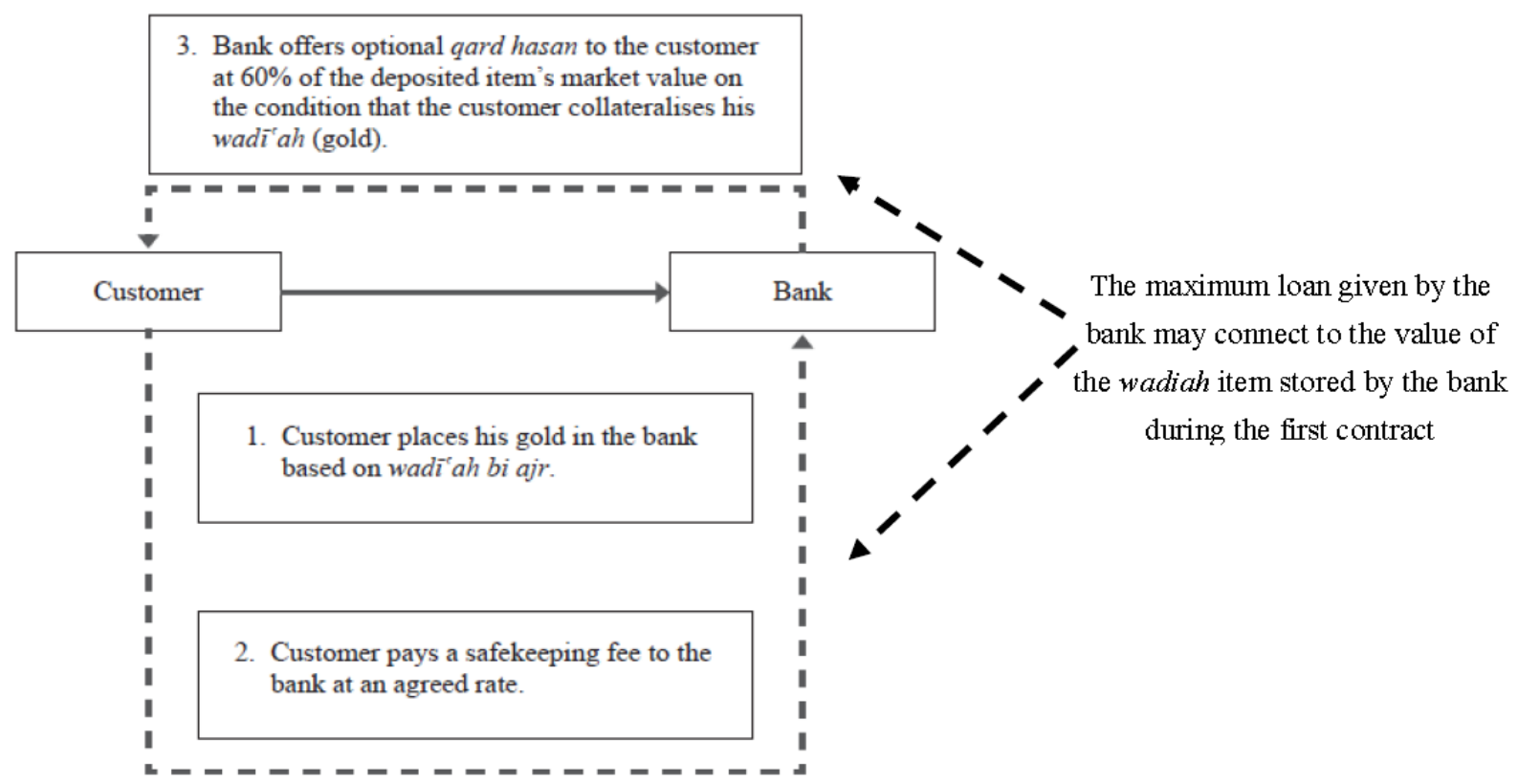

Figure 2. The process flow of the composite contract of wadiah bi ajr, qard hasan and rahn al-wadiah

Source: Khir (2011)

However, this hiyal-based contract may be avoided if the model suggested by Mukhlas could be further examined. The suggested model consists of the contracts of murabahah and al-rahn. The figure 3 below shows on how this model operates. The parties entered into a composite contract in the MULIA financing are:

First, the pawnshop as a buyer or financier of the goods purchased. Second, the customer as a buyer of goods in the MULIA commodity financing (gold) and third, the supplier or a party authorized by the pledgee to sell the goods. (In this case, the supplier is PT.Aneka tambang).

The pawnshop (the first party) is to finance the purchase of gold bar ordered by the customer or purchaser (second party). The purchasing is made to the supplier (third party). Purchase of goods or commodities by the customer (the first) is done with deferred payment system. In practice, the pawnshop buys the goods and sells them to their customers for principal amount plus a profit to be paid by the customer at a certain period. Then the commodity (gold bar) that is bought has made up as a guarantee (marhun) for the amortization of customer remaining debt to the pawnshop. After all outstanding customer paid the gold bar; the documents will be submitted to the customer.

Based on the transaction could solve the shari'ah issue of what it cannot be done in the previous contract; however, the selling price of gold bar will be questioned if the price is above the market price. The above market price of selling gold bar seems unavoidable as the pawnbroker need to get some profit on it. Even the issue of ujrah fee will be resolve but the incident of hiyal (trick) and suspicious riba as what has been mentioned previously could be affected. 


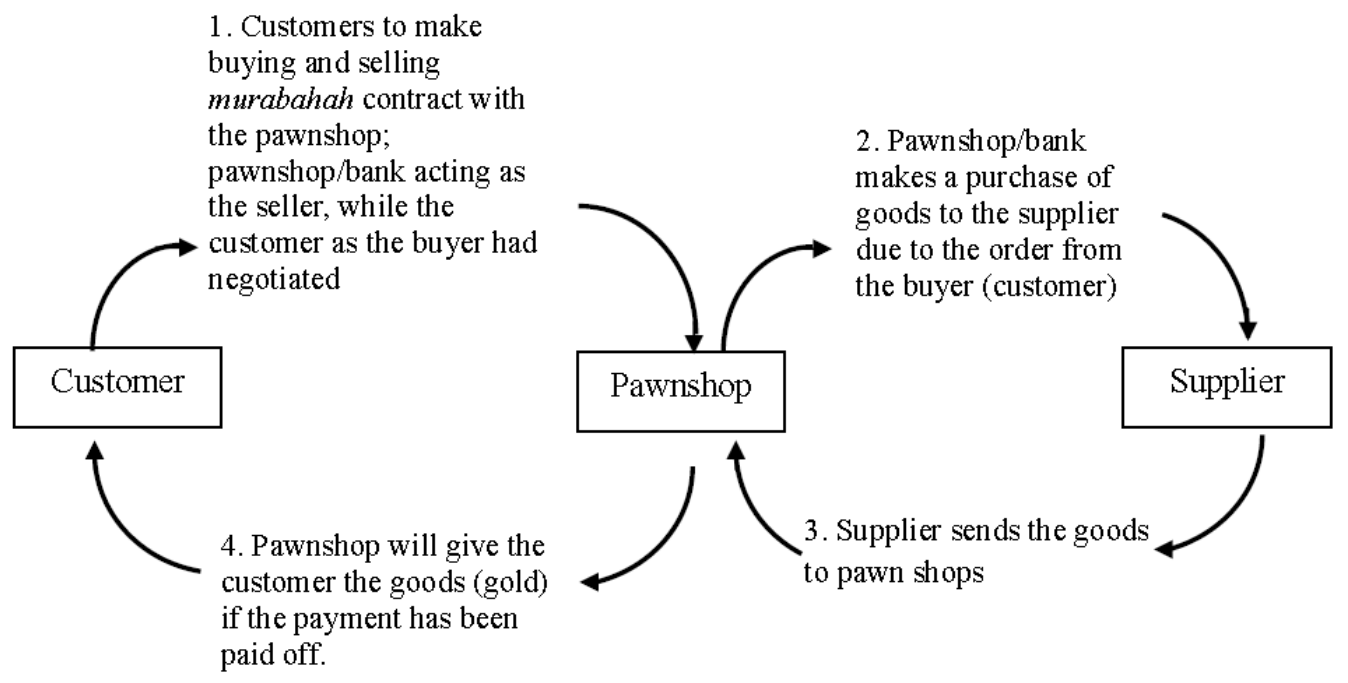

Figure 3. The process flow of the composite contract of Murabahah and al-rahn

Source: Mukhlas (2010)

$2^{\text {nd }}$ feature: The possibility of longer repayment's period

The current practice of ar-rahn requires customers to repay the loan and redeem the pawned item within 6 month and given the option of the extension for another 6 month. Based on the table 1, we believed that a 6 month period is not being able to serve a good substitute to the existing financing that mostly offered 5 years period and above. The longer period is essential as many people are willing to be given more time of repayments for their loan. This also could avoid the risk of default and encourage people to pay a loan steadily. In ar-rahn contract, another 6 month of extension period is given only when the ujrah fee for the first 6 month of period is been settled. This will lead to a double charge of ujrah fee as it is imposed for a second time in the sixth month extension period contract.

For instance, assume the value of marhun is RM10, 000 and the maximum amount of loan that can be offered by bank or pawnshop is only $70 \%$ from the total value of marhun which is RM7, 000. Thus, the ujrah fee can be calculated based on this formula (Malaysia, t.t.):

$$
\mathrm{US}=\underline{\mathrm{NM}} \times \mathrm{K} \times \mathrm{T}
$$

Where:

NM = Marhun Value (Pledge item's value)

$K=$ Rate

$T=$ Duration (month)

Ujrah fee $=10,000 / 100 \times 0.75 \times 6$

$=\mathrm{RM} 450$

Assume that the pledgor does not yet to repay any amount in the first 6 month of period, thus the ujrah fee will be charge for a second time by a similar amount.

The ujrah fee after the period of extension

$=10,000 / 100 \times 0.75 \times 6 \times 2$

$=$ RM900

In this case, a double charge of ujrah fee can be seen if one could not be able to repay the loan and redeem the pledge in a first 6 month but one could save a similar amount of money from being charged once again if he manages to settle the loan. This situation is likely not giving a good advantage to the pledgor as mostly they need more time to repay the loan. This disadvantage situation is likely give the bank chances to get more money through the extension of time. This situation is unfair to the pledgor as the opportunity to redeem the pledge in 6 month seems tightening but at the same time the bank has deep concerned on the income generation. As a solution, the imposing of one time ujrah fee in a year will be a good alternative as the pledged item has already 
at their possession. At the same time, the bank probably could increase the financing amount as they giving up the higher rate as what other financing products have done. Table 1 will give a brief picture on how the rate could tolerate to the amount of financing

$3^{\text {rd }}$ feature: The minimization of the shariah and economic issue of ujrah fee.

This work concentrates relevant issue from each shari'ah and economic perspective. In shari'ah perspective, the issue of linking ujrah fee to the value of the pledge is being examined as the current concept by the bank has led to the actual riba. Even though Khir suggested the composite contracts of wadiah bi ujr, qard hasan and rahn al-wadiah model and claimed it was removed from the direct linkage of the ujrah fee to the value of the pledge, there are two questions become essential to be further examined. One of them is the use of the similar pledge in the two different contracts which are wadiah bi ajr and rahn al-wadiah. The use of similar wadiah item (normally gold) in two different contracts is still not enough in validating the removal of direct linkage of the ujrah fees and the pledge.

To see a clear picture, a process flow of these contracts is illustrated in figure 2. The similar item was identified in step 1 and 3 of the flow even their contract implications are different. In step 1, the customer is already places his gold based on wadiah bi ajr which then ended as a guaranty of the pledge by the bank. The payment of ujrah fee for the bank meaning that the bank has to safe keep the gold and it will be affecting the bank to guarantee the wadiah which is the gold. Then, in step 3, the similar gold that has been kept by bank is once again entering into the second contract which is ar-rahn contract that ended as a security for the loan. Unless the strong justification is being given, the issue of the removal of linking ujrah fee to the value of loan is remaining unsolved. One could argue and get back the gold from the contract based on wadiah bi ajr after made full settlement of the ujrah fee just because of the reason wadiah bi ajr contract is separated with the rahn al-wadiah contracts. This is because the separation of contract is the only way to validate the removal of the linkage.

The second issue of shari'ah perspective is the absence of a clear justification of the ujrah fee rate charged by the bank and pawnshop. Is the rate of ujrah fee really based on the storage box? Or the other justifications such as weight of the pledge and the risk of losses are about to concern? If those justifications are included in determining the rate, then what kind of measuring standard are to be followed? Those questions are crucial to be reviewed and discoursed.

In term of economic issue, the rate of ujrah fee should be well-suited with the requirement that the banks had imposed. Based on the table 1, if a head to head comparison to the other financing product, ar-rahn is the only product that requires the collateral and yet the rate is much higher than the others which it has not. The $12.85 \% \mathrm{a}$ year with a strong back up by the pledged item obviously not reach into a level that it has a good competitive rate. The solution could be made is to adjust the rate by increasing the maximum amount of loan and extending the period of repayment. This probably could be done by offering various options of ar-rahn categories as what the product of financing has done. For instance, ar-rahn based product may offer different categories of rate, loan amount and period for different purposes.

$4^{\text {th }}$ feature: The possibility of offering more than RM10, 000 borrowing money

The pawn broking act 1972 had clearly stated not more than RM10, 000 only being allowed to be offered to the customers. This timeworn justification of maximum amount is obviously should be changed as the amount had determined 40 years ago. Based on the current gold prices and consumer goods, the need of the amendment for the amount of borrowing cash is significantly necessary. If one wishes to pledge three ounces of her jewelries today, he or she might not be able to utilize the maximum loan from his or her peldge as the act restricted by the maximum amount of RM10, 000.

Table 2. Change in percentage of gold prices in 5, 10 and 20 years

\begin{tabular}{ccccc}
\hline \multirow{2}{*}{ Year } & Price (Dollar)/oz. & \multicolumn{2}{c}{ Percentage Change (+/-) in three set of period } \\
\cline { 3 - 4 } & 70 & $\mathbf{5}$ years & 10 years & 20 years \\
\hline 1972 & 168 & - & & \\
1977 & 488.50 & $+140 \%$ & & \\
1982 & 502.75 & $+190.7 \%$ & $+597 \%$ & \\
1987 & 359.60 & $+2.9 \%$ & & $+413.7 \%$ \\
1992 & & $-26 \%$ & $-26 \%$ &
\end{tabular}




\begin{tabular}{ccccc}
1997 & 367.8 & $0.2 \%$ & & \\
2002 & 342.75 & $-6.8 \%$ & $-4.6 \%$ & \\
2007 & 841 & $+145 \%$ & & $+357.7 \%$ \\
2012 (until July) & 1646.51 & $+95.7 \%$ & $+380 \%$ & $\mathbf{+ 3 8 5 . 7 \%}$ \\
\multicolumn{2}{c}{ Average Percentage Change (+/-) } & $\mathbf{+ 6 7 . 6 \%}$ & $\mathbf{+ 2 3 6 . 6 \%}$ &
\end{tabular}

Source: http://www.kitco.com/charts/historicalgold.html

From the table 2, we can see the increasing prices of gold were soared in three different set of period. The average percentage of change for 5, 10 and 20 years' time have increased $67 \%, 236 \%$ and $385 \%$ respectively. This shows a growing percentage in the long run was tremendously gargantuan. The longer period engaged the bigger change in gold prices. This situation shows the bank and customers are mutually gained if the period will be extended up to 20 years. The customer will enjoy the access of big amount of loan and the bank will get a long commitment of income from the customers through monthly installment.

However, in the table 3 , the average percentage of change in gold prices within a year has decreased $0.8 \%$. This situation is not favorable to both parties due to the fluctuation of gold prices each month. The customers are unable to enjoy more time in repayment for redemption. This situation does not encourage a customer to make a monthly payment to the loan provided by the bank. For the bank, a shorter period of debt-based contract will only give them a shorter commitment from the customers as well as the return.

Table 3. Change in percentage of gold prices in a year-time (2012)

\begin{tabular}{cccc}
\hline Year & Month & Price (Dollar)/oz. & Percentage Change (+/-) \\
\hline \multirow{3}{*}{2011} & Aug & 1755 & $+0.9 \%$ \\
& Sept & 1771 & $-5.9 \%$ \\
& Oct & 1665 & $+4.3 \%$ \\
& Nov & 1738 & $-4.9 \%$ \\
& Dec & 1652 & $+0.2 \%$ \\
& Jan & 1656 & $+5.19 \%$ \\
& Feb & 1742 & $-3.9 \%$ \\
& Mac & 1673 & $-1.3 \%$ \\
& April & 1650 & $-3.9 \%$ \\
& May & 1585 & $+0.6 \%$ \\
& June & 1596 & $-0.2 \%$ \\
& July & 1592 & $\mathbf{- 0 . 8 \%}$ \\
\hline
\end{tabular}

Source: $\quad$ http://www.onlygold.com/tutorialpages/picessince1972fs.htm

http://www.kitco.com/charts/historicalgold.html

$5^{\text {th }}$ feature: The receivable of pledge item.

Recently, the bank only receives gold jewelries as the pledge item as guarantee for the loan borrowed. Even the gold has its own intrinsic and strong value, when it comes to the form of bar or coin for instance, it is no longer accepted. This may scale down the people to engage ar-rahn product as they are not only comes from women community but also from the businessmen and investors. This is contrast of what Islam suggested about the pledge that can be accepted from any goods that has strong own value. Even though the plants, fruits, animals and other perishable goods are mentioned in Islamic jurisprudence, the goods that have not facing depreciation in the long run are given the priority. For time being, regardless of its form, any gold metal should be accepted in the contract as it carries a strong and stable value and demand.

\section{Conclusion}

The discussion of the improvement of ar-rahn is one of the efforts of upgrading the existing products. The process is not to eliminate the existing product but rather to highlight a wider choice to consumers in engaging the mechanism of financing from the debt-based contract. The existing ar-rahn product will be better when its 
potential is developed to a certain extent it could and eventually becomes a good alternative product in the financial markets. This is only the beginning of a continuing effort that should be further reviewed in the future for the good of the parties involved.

\section{References}

(1965). Section 242-243 of National Code Land (Act No. 56). Kuala Lumpur: Malaysian Law.

Al-Bukhari, M. B. (810-870M/194 - 256H). Al-Jami' al-Musnad Al-Sahih al-Mukhtasar min umur Rasulillah wa sunanihi wa ayyamihi (1st ed., Vol. 4). Dar Tauq al-Najah.

Al-Du'ailaj, M. B. (1986). A Pledge in Islamic Jurisprudence (Original text: للرهن في الفقه السلامي). Riyadh: University of Imam Muhammad bin Saud al-Islami.

Al-Naisaburi, M. I.-H.-H.-Q. (n. d.). Al-Musnad al-Sahih al-Mukhtasar bi al-Naql al-Adl An al-Adl ila Rasulillah (1st ed., Vol. 3). Beirut: Dar Ihya al-Turath Al-Arabi.

Al-Qurashi, A. A.-F. (1999). Tafsir al-Quran al-Azim (2nd ed., Vol. 1). Riyadh: Dar Taiyyibah Li al-Nasyar wa al-Tauzi'.

Al-Sahmi, M. B. (1989). Al-Maghazi (3rd ed., Vol. 2). Beirut: Dar al-'Alami.

Al-Tamimi, A. A.-R.-W. (1991). Al-Iman wa al-Radd 'Ala Ahl al-Bid' (3rd ed., Vol. 1). Riyadh: Dar al-'Asimah: Riyadh.

Bashir Ahmad, S. A., Mansor, N., \& Nadiah, A. N. (2012). Customer Acceptance On Islamic Pawn Broking: A Malaysian Case. Interdisciplinary Journal Of Contemporary Research In Business, 3(10), 748-763.

Hussein, S. A. (2000). Ar-Rahn: Factors Affecting Customers' Perception towards the Islamic pawn schemes. Case Study: Ar-rahn Shop in Kangar, Perlis. Faculty of Business Management. Sintok, Kedah: Universiti Utara Malaysia.

Ibrahim, U., \& Salleh, S. (2006, August 8-10th). The objectives of al-rahn and their achievement in charge/mortgage in Islamic home financing: an analysis". The International Conference on Islamic Jurisprudence and the Challenges of the 21st Century. Kuala Lumpur: IIUM.

Ismail, A. G., \& Ahmad, N. Z. (1997). Pawnshop as an instrument of microenterprise credit in Malaysia. International Journal of Social Economics, 11(24), 1343-1352. http://dx.doi.org/10.1108/03068299710193633

Khir, M. F. (2011). Revisiting the Fiqh Characterizations of The Rahn-Based Islamic Microcredit Product. ISRA International Journal of Islamic Finance, 3(2), 151-157.

Maamor, S., \& Ismail, A. G. (2010). The Ar-Rahn Efficiency and Its Determinants. Journal of Islamic Economics, Banking and Finance, 6(1).

Malaysia, Y. P. (t. t.). Ar Rahnu-Based Micro Credit Programme. Kuala Lumpur: YAPEIM.

Masae, S. (2011). Pawning practices in Muslim societies of Pattani, Thailand, according to Islamic perspective (Original text: Amalan pajak gadai dalam masyarakat Islam Pattani, Thailand menurut perspektif Islam. Kuala Lumpur: University of Malaya.

Mohamad, S. (1995). Pawnbrokers Act 1972: An Analysis from the Islamic Perspective (Original text: Akta Pemegang Pajakgadai 1972: Suatu Analisa Dari Perspektif Islam). Jurnal Syariah, 3(2), 277-284.

Mohamad, S. (2004). The Implementation of Islamic Mortgage in Islamic Mortgage Institutions in Malaysia: Case Study in Terengganu Islamic Pledge Muassasah (Original text: Pelaksanaan Gadaian Islam Di Institusi-Institusi Gadaian Islam Di Malaysia). Kuala Lumpur: University of Malaya.

Mukhlas. (2010). Implementation of Islamic Mortgage by using Murabaha and Rahn contract: A study on Islamic pawnshop branch Mlati Yogyakarta Sleman. Surakarta: Universitas Sebelas Maret.

Mydin Meera, A. K. (2009). Integrating al-rahn with the gold dinar: the initial building-blocks towards a gold-based economy. In A. K. Mydin Meera (Ed.), Real money: Money and Payment systems from an Islamic perspective (pp. 221-235). Kuala Lumpur: IIUM Press.

Naim, A. M. (2004). Islamic Pawn Broking System (Original text: Sistem Gadaian Islam). Islamiyyat, 26(2), $39-57$. 
Rosly, S. A. (2007). The Role of Khiyar al-‘Ayb in al-Bay' Bithaman Ajil Financing. International Journal of Islamic Financial Services, 2(3).

Salleh, S. (2005). Islamic Mortgage System: Practice and effectiveness of its operations in Perlis (Original text: Sistem Gadaian Islam: Pengamalan Dan Keberkesanan Operasinya Di Negeri Perlis). Kuala Lumpur: University of Malaya.

Seman, R. H. (1994). Islamic Mortgage: The concept and implementation in Terengganu Muassasah of Islamic Mortgage (MGIT). The Academy of Islamic Studies, Faculty of Shariah. Kuala Lumpur: University of Malaya.

Shakhanbeh, S. A. (2010). Collaterals in kind and the extent of the legitimacy of its investment by Islamic bank (Original text: الضمانات العينية الرهن و مدى مشروعيات استثمارها في الدصارف الإسلامية). Jordan: Arabic Academy for Finance and Banking.

Spradley, J. (1979). The Ethnographic Interview. Orlando: Holt, Rinehart, \& Winston.

Yamani, A. B. (1403 h). al-Musannif (2nd ed., Vol. 8). Maktab al-Islami.

Yunta, A. H. (2007). The ruling of pledge utilization: Its applications in Shariah Pawnshop of Makassar, South Sulawesi" (Original text: Hukum Permanfaatan Harta Gadaian Aplikasinya dalam Pegadaian Shariah di Makassar, Sulawesi Selatan. Bangi: Universiti Kebangsaan Malaysia.

\section{Appendix}

\section{HISTORICAL LONDON SDOT GOLD DRICES}

Annual High \& Low Gold Bullion Prices Since 1972

\begin{tabular}{|c|c|c|c|c|c|}
\hline Year & $\begin{array}{l}\text { Yearly } \\
\text { High }\end{array}$ & $\begin{array}{l}\text { Yearly } \\
\text { Low }\end{array}$ & Year & $\begin{array}{l}\text { Yearly } \\
\text { High }\end{array}$ & $\begin{array}{l}\text { Yearly } \\
\text { Low }\end{array}$ \\
\hline 1972 & $\$ 70.00$ & $\$ 44.00$ & 1990 & $\$ 423.75$ & $\$ 345.85$ \\
\hline 1973 & $\$ 128.00$ & $\$ 84.00$ & 1991 & $\$ 403.00$ & $\$ 344.30$ \\
\hline 1974 & $\$ 195.00$ & $\$ 117.00$ & 1992 & $\$ 359.60$ & $\$ 330.20$ \\
\hline 1975 & $\$ 185.00$ & $\$ 135.00$ & 1993 & $\$ 406.70$ & $\$ 326.10$ \\
\hline 1976 & $\$ 142.00$ & $\$ 102.00$ & 1994 & $\$ 397.50$ & $\$ 369.65$ \\
\hline 1977 & $\$ 168.00$ & $\$ 127.00$ & 1995 & $\$ 396.95$ & $\$ 372.40$ \\
\hline 1978 & $\$ 243.65$ & $\$ 165.70$ & 1996 & $\$ 416.25$ & $\$ 367.40$ \\
\hline 1979 & $\$ 524.00$ & $\$ 216.55$ & 1997 & $\$ 367.80$ & $\$ 283.00$ \\
\hline 1980 & $\$ 850.00$ & $\$ 474.00$ & 1998 & $\$ 314.60$ & $\$ 273.40$ \\
\hline 1981 & $\$ 599.25$ & $\$ 391.25$ & 1999 & $\$ 323.50$ & $\$ 252.80$ \\
\hline 1982 & $\$ 488.50$ & $\$ 298.75$ & 2000 & $\$ 325.50$ & $\$ 264.10$ \\
\hline 1983 & $\$ 511.50$ & $\$ 374.25$ & 2001 & $\$ 291.45$ & $\$ 256.65$ \\
\hline 1984 & $\$ 406.85$ & $\$ 303.25$ & 2002 & $\$ 342.75$ & $\$ 277.75$ \\
\hline 1985 & $\$ 340.90$ & $\$ 284.25$ & 2003 & $\$ 417.25$ & $\$ 319.90$ \\
\hline 1986 & $\$ 442.75$ & $\$ 326.00$ & 2004 & $\$ 454.20$ & $\$ 375.00$ \\
\hline 1987 & $\$ 502.75$ & $\$ 390.00$ & 2005 & $\$ 536.50$ & $\$ 411.10$ \\
\hline 1988 & $\$ 485.30$ & $\$ 389.05$ & 2006 & $\$ 725.00$ & $\$ 524.75$ \\
\hline \multirow[t]{5}{*}{1989} & $\$ 417.15$ & $\$ 358.50$ & 2007 & $\$ 841.10$ & $\$ 808.40$ \\
\hline & & & 2008 & $\$ 1,011.25$ & $\$ 712.50$ \\
\hline & & & 2009 & $\$ 1,212.50$ & $\$ 810.00$ \\
\hline & & & 2010 & $\$ 1.421 .00$ & $\$ 1,058.00$ \\
\hline & & & 2011 & $\$ 1,895.00$ & $\$ 1,319.00$ \\
\hline
\end{tabular}

Source: http://www.onlygold.com/tutorialpages/picessince1972fs.htm 